\title{
Measuring Protein Synthesis Rate In Living Object Using Flooding Dose And Constant Infusion Methods
}

\author{
Ulyarti $^{*}$ \\ \# Technology of Agricultural Product Department, University of Jambi, Indonesia \\ E-mail:ulyarti@unja.ac.id
}

\begin{abstract}
Constant infusion is a method used for measuring protein synthesis rate in living object which uses low concentration of amino acid tracers. Flooding dose method is another technique used to measure the rate of protein synthesis which uses labelled amino acid together with large amount of unlabelled amino acid. The latter method was firstly developed to solve the problem in determination of precursor pool arise from constant infusion method. The objective of this writing is to compare the results from several researches on measuring protein synthesis rate using flooding dose and constant infusion methods and to obtain the criteria or prerequisite on the type of sample and tracer for each method. The measurements of protein synthesis rate using both methods are presented and results from both methods are compared. Both methods are eligible for measuring protein synthesis rate as long as the true precursor can be measured. The uncertainties in determining the precursor in constant infusion method and the effect of flooding on the stimulation of protein are the limitation on using the two methods. Bolus injection which imitates the flooding dose method but using smaller dose of tracer can be a good alternative in measuring protein synthesis rate.
\end{abstract}

Keywords_ protein synthesis rate; constant infusion; flooding dose; precursor

\section{INTRODUCTION}

Proteins are synthesized by incorporating amino acids in special order which is determined by the genes. This order will determine the structure and the function of the proteins. Proteins are constantly being synthesized and broken down. Assessing the rate of protein synthesis is important in many ways. The rate of protein synthesis, together with the rate of protein breakdown, gives information about growth or recovery of tissue mass after disease or injury. Understanding protein synthesis will help people to minimise muscle wasting, slow the rate of ageing, quicken wound healing, minimise the impact of trauma, etc. There are some proteins which seem to have effect on the increase of protein synthesis rate which allows us to formulate diet for specific cases.

Protein synthesis is usually assumed as a zero order process which can be calculated in terms of a fractional synthetic rate (FSR). FSR of protein is the proportion of the total protein pool which is added per unit of time [1]. When a particular amino acid tracer is used, FSR of protein usually be expressed in amounts of amino acid incorporated to the protein per tissue mass per unit of time. Therefore, to calculate the rate of protein synthesis researchers need to measure the amount of protein-bound amino acid and the amount of precursor (amino acid) for protein synthesis.

The measurement of protein-bound amino acid is quite straight forward. On the other hand the measurement of precursor amino acid presents a practical problem. The true precursor pool for protein synthesis is aminoacyl t-RNA [2]. However, the measurement of this molecule is difficult because it is present in low concentration within tissues [3] and performs high turnover [2]. Instead, free amino acid in the tissue fluid (intracellular) or free amino acid in the plasma (extracellular) is measured. These intra or extracellular free amino acid is used as precursor pool of protein synthesis with assumption that the enrichment of these precursors are at equilibrium with enrichment of aminoacyl tRNA as the true precursor [2].

There are two methods which widely used to measure the rate of protein synthesis: flooding dose method and constant infusion or trace dose method. These methods differ in the approach of measuring the precursor pool. Constant infusion method uses trace dose of amino acid tracer which is constantly infused to the tissue or cells for several hours [411]. The plateau level of precursor is normally achieved after few hours of infusion. On the other hand, in flooding dose method, measurement of amino acid precursor is performed by flooding the tissue or cells with labelled amino acid together with abundant unlabelled amino acid [12-19]. The plateau level of precursor normally achieve soon after flooding. The discrepancies of FSR of proteins measured using these two methods show that there might be some condition to be understood before performing the experiment using either method. There are several factors that may lead to these discrepancies including types of sample, isotopes, and type of amino acid tracer. The objective of this writing is to compare the results from several researches on measuring protein synthesis rate using constant infusion and flooding dose methods. 


\section{MAterial AND Methods}

This writing is based on the information from references in the sciencedirect.com using keywords prosein synthesis rate using constant infusion and flooding dose. In general the measurement of protein synthesis rate need:

\section{A. Isotopes}

The isotopes which have been used in this experiment are ${ }^{2} \mathrm{H}_{2} \mathrm{O}$, L- $\left[\mathrm{U}_{-}{ }^{14} \mathrm{C}\right]$ proline, $\mathrm{L}-\left[1-{ }^{13} \mathrm{C}\right]$ valine, ${ }^{13} \mathrm{C}$ - valine, $\mathrm{L}-{ }^{3} \mathrm{H}-$ leucine, $\left[{ }^{2} \mathrm{H}_{3}\right]$ leucine, L- $\left[1-{ }^{13} \mathrm{C}\right]$ leucine, $\left[{ }^{15} \mathrm{~N}\right]$ glycine, L[ring $\left.{ }^{2} \mathrm{H}_{2}\right]$ tyrosine, $\left[{ }^{15} \mathrm{~N}\right]$-tyrosine, ${ }^{14} \mathrm{C}$-tyrosine, ${ }^{3} \mathrm{H}$-tyrosine, L$\left[{ }^{2} \mathrm{H}_{5}\right] \quad$ phenylalanine, L-phenyl $\left(2,3-{ }^{3} \mathrm{H}\right)$ alanine, ${ }^{3} \mathrm{H}$ phenylalanine, ${ }^{14} \mathrm{C}$ phenylalanine, $\mathrm{L}-{ }^{15} \mathrm{~N}$-phenylalanine, and $\mathrm{L}$-[ring- ${ }^{13} \mathrm{C}_{6}$ ]-phenylalanine

\section{B. Subjects}

Varies of subjects have been included in the study: rats, fish, dog, caco-2 cells, healthy human, young human, elderly, cancer patients, and COPD patients.

\section{Study Protocols}

The study protocols strongly depend on the treatment applied and focus of the research. For example in the study of muscle protein synthesis, the muscle biopsy is taken while the study of plasma protein synthesis, the blood sample is taken. However, the general protocol for flooding dose method and constant infusion method are shown in Figure 1 and 2 below.

\section{Sample Processing and Analysis}

The samples are immediately processed or frozen to stop or at least to minimise the changes that might occur in the samples. The isotopic enrichment of free amino acid precursor can be done using GC-MS or by spectrofotometry. Separate protocol is needed for every type of amino acid analysis. Protein-bound amino acid enrichment is done by similar methods to free amino acid precursor. This can be done with or without previously being hydrolised into its amino acids units. In constant infusion method, the amino acid precursor mostly is considered to be in the tissue fluid, while in flooding dose the precursor can be taken from either blood sample or tissue fluid. The calculation of protein fractional synthesis rate (FSR) is shown in eq.(1).
Blood sampling Animal killing Tissue sampling

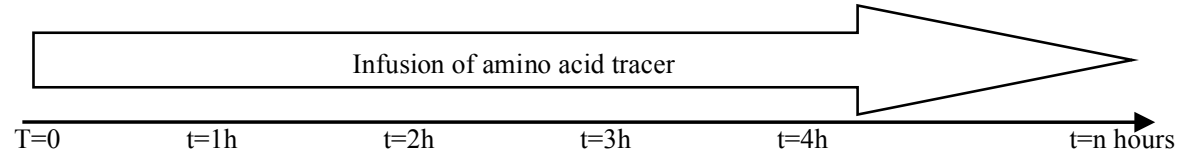

$\mathrm{X}$

$\mathrm{x} \quad \mathrm{x}$

Fig 1. General study design for constant infusion method.

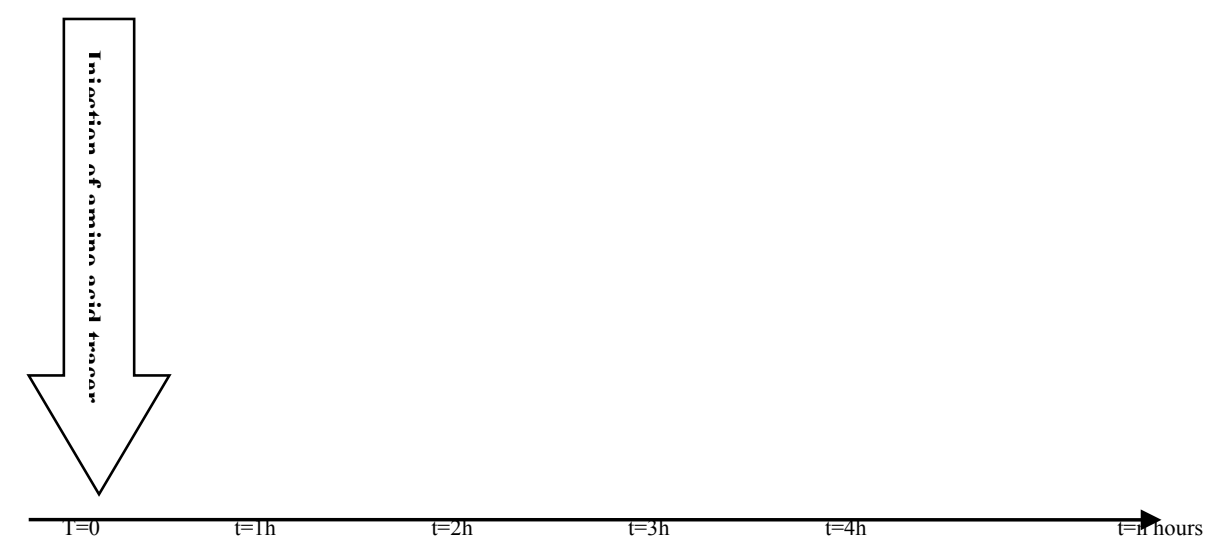

Fig. 2. General study design for flooding dose method 
$\operatorname{FSR}(\% /$ day $)=\frac{\left(E_{b 2}-E_{b 1}\right)}{\bar{E}_{a}} \times \frac{24}{t_{2}-t_{1}} \times 100$

$E_{b 1}$ is Enrichment of protein-bound amino acid at $t_{1}$

$E_{b 2}$ is Enrichment of protein-bound amino acid at $t_{2}$

$E_{b 2}-E_{b 1}$ denotes the amount of amino acid that accumulates in the protein during the course of an experiment.

$\bar{E}_{a}$ is the average of enrichment of free amino acid precursor from $t_{1}$ to $t_{2}$.

$t_{1}$ and $t_{2}$ are time (in hours).

In constant infusion method, this can be seen clearly from which the samples are taken. In flooding dose, $t_{1}$ is the injection time while $t_{2}$ is the time when protein sample is taken to be immediately processed or the time when the sample is frozen.

\section{RESUlT AND DISCUSSION}

The determination of in vivo synthesis of protein is safely possible, even in human, using infusion of amino acid tracer labelled with stable isotopes. In animal or culture cell, the determination of in vivo synthesis can be performed using amino acid tracer labelled with radioactive. The use of radioactive or stable isotopes labelling is intended to trace the appearance of amino acid in the product (protein). The measurement of the appearance of the trace in the product can be performed at the end of experiment. As protein is being synthesized and degraded constantly in living cells, the measurement must not be taken in a long time as the protein might have undergone degradation and the amino acid turn back to the precursor pool. Furthermore, the amino acid in the tissue being studied must not have pathway other than being incorporated to the new protein.

There is one experiment using constant infusion method which have a very long term infusion up to 16 hours [7] during which proteolysis already occurred and underestimate the rate of protein synthesis. Many experiments using constant infusion method used period of infusion of 4 to 6 hours and plateau levels were achieved at the end of the infusion. Everett et al. [4] showed that the equilibrium between intracellular compartment and plasma was achieved only in 2 hours after constant infusion (Figure 3). As seen in Figure 3 below, the enrichment of tissue free pool was approximately $80 \%$ that of plasma. This showed that although plateau in the plasma enrichment has been achieved, the value for tissue free pool is still lower than that of plasma. This lead to uncertainties associated with the assignment of the enrichment of the true precursor pool when experiment is performed using constant infusion method.

The flooding dose method aims to equalize the isotopic enrichment in all free amino acid pools, thus simplifying the measurement of precursor enrichment [20]. In this technique, true constancy of enrichment over a short period of measurement is not achieved but it is relatively easy to make estimates the rate of change of the enrichment in the free pool from plasma measurement [1]. As shown in Figure 4 and 5 below, the enrichment of intracellular free pool (imitating the tissue free pool) and extracellular free pool (imitating the plasma free pool) reached plateau only after 30 minutes of flooding.

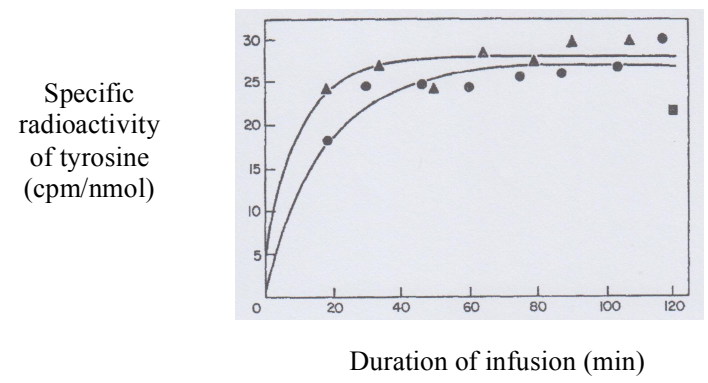

Fig. 3. Specific radioactivity of tyrosine in arterial plasma $(\mathbf{A})$, venous plasma $(\bullet)$ and tissue free pool (๘) during constant infusion in the $\operatorname{dog}[4]$

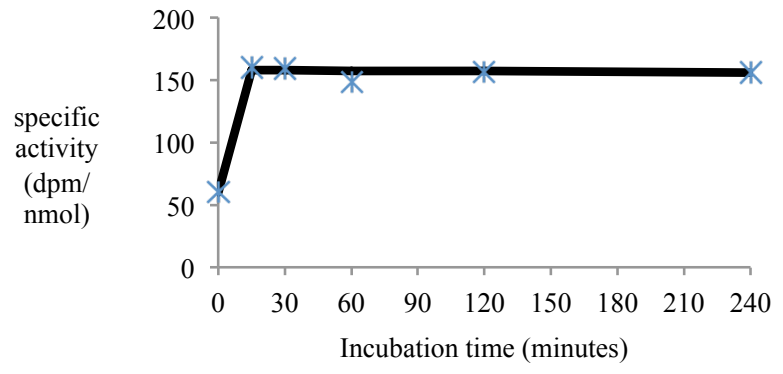

Fig.4. Time course of the change in specific activity of intracellular free phenylalanine in Caco-2 cells after flooding with [ring $\left.2,4^{3} \mathrm{H}\right]$ phenylalanine; values came from a single measurement [21]

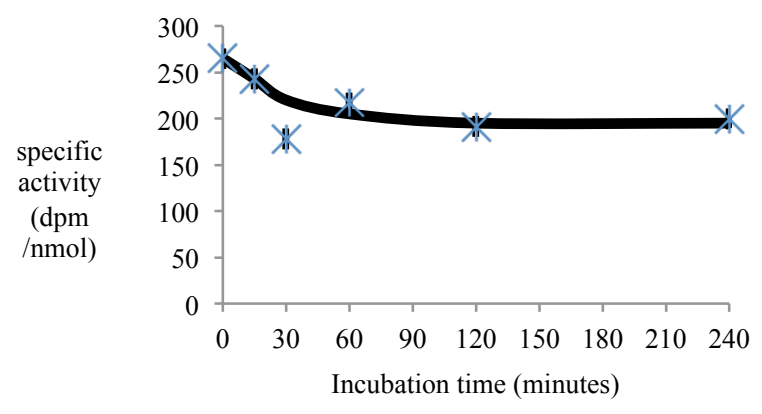

Fig. 5. Time course of the change in specific activity of extracellular free phenylalanine in Caco-2 cells after flooding with [ring $\left.2,4^{3} \mathrm{H}\right]$ phenylalanine; values came from a single measurement [21]

The comparison of FSR of protein measured using flooding dose method and constant infusion method is found to be difficult to make. This is due to the limitation on finding the reference on measuring FSR of protein on exactly the same sample and amino acid tracer but using different method. As shown in Table 1 below, experiment on measuring FSR of 
TABLE I

FSR Of Protein From SEVERAL SAmples MeAsured Using FloOding Dose AND Constant INFUSION

\begin{tabular}{ccccc}
\hline Method & Sample & Tracer & FSR (\%/day) & Reference \\
\hline CI & Fish muscle & ${ }^{14} \mathrm{C}$ L tyrosine & $0.6-1.8$ & {$[5]$} \\
\hline FD & Cat fish muscle & ${ }^{2} \mathrm{H}$ alanine & 0.96 & {$[17]$} \\
\hline FD & Toadfish muscle & ${ }^{14} \mathrm{C}$ phenylalanine & $0.2-0.23$ & {$[12]$} \\
\hline CI & Human skeletal muscle & ${ }^{2} \mathrm{H}_{5}$ phenylalanine & $2.64-2.88$ & {$[9]$} \\
\hline CI & Human skeletal muscle & {$\left[\right.$ ring- $\left.{ }^{13} \mathrm{C}_{6}\right]$-phenylalanine } & 1.92 & {$[11]$} \\
\hline CI & Human skeletal muscle & L-[ring- $\left.{ }^{2} \mathrm{H}_{5}\right]$-phenylalanine & 1.58 & {$[22]$} \\
\hline FD & Human enterocyte & ${ }^{13} \mathrm{C}$-valine & $10.9 \pm 8.1$ & {$[15]$} \\
\hline CI & Human enterocyte & phenylalanine & $50-100$ & {$[23]$} \\
\hline CI $\cdot$ Constant Infusion; FD $:$ Flooding Dose & & &
\end{tabular}

protein in human skeletal muscle all were performed using constant infusion method. None is found to be performed using flooding dose method. Furthermore, experiments on measuring FSR of protein in human enterocytes were found to be performed using both methods but using different tracer. The best comparison can be made if the type of the sample as well as the amino acid tracer is the same. In the present time, this is only available on experiment done by Jahoor et al [24]. Similar experiment was done by Tuvdendorj et al [22] who performed bolus injection, a protocol similar to flooding dose but using smaller dose.

Jahoor et al. [24] initially showed that different isotopes of leucine as tracers gave almost identical value on the FSR of protein. The experiment on flooding dose and constant infusion method hence could be performed using different isotope of the same amino acid tracer. The FSR of protein measured using flooding dose method gave markedly greater value than that when using constant infusion method. In contrast, the flooding of unlabelled amino acid at a time during experiment using constant infusion method showed to decrease the FSR of protein. This showed that constant infusion method is not valid when a large amino acid (in case of muscle the amino acid is leucine) is used in the experiment.

Stimulation of synthesis from flooding dose method seems to occur only when using essential amino acid [1]. When the use of amino acid essential can not be avoided, a bolus injection which uses smaller dose than flooding dose method, is a good choice. Tuvdendorj et al. [22] showed that FSR of muscle protein synthesis in human using bolus injection and constant infusion method gave almost identical results.

\section{CONCLUSION}

Flooding dose and constant infusion methods are eligible for measuring protein synthesis. However, the use of many type of amino acid tracer on different types of samples in many experiments leads to inability to compare the FSR of protein using both methods. To our best knowledge, there is only one experiment which compares the two methods. In this experiment, flooding dose method gave markedly higher value of FSR of protein than constant infusion method. The uncertainties in determining the precursor in constant infusion method and the effect of flooding on the stimulation of protein are the limitation on using the two methods. Bolus injection which imitates the flooding dose in the approach to measure the precursor enrichment but using smaller dose of tracer can be a good alternative in measuring protein synthesis rate.

\section{REFERENCES}

[1] Smith K and Rennie MJ. 1996. The measurement of tissue protein turn over. Bailliere's Clinical Endocrinology and Metabolism 10: 469-495

[2] Waterlow JC, Garlick PJ, Milllward DJ. 1978. Protein Turn Over In Mammalian Tissues And In The Whole Body. Amsterdam:North Holland

[3] Davis TA, Fiorotto ML, Nguyen HV, Burrin DG. 1999. AminoacyltRNA and tissue free amino acid pools are equilibrated after a flooding dose of phenylalanine. Am J Physiol Endocrinol Metab 277: 103-109

[4] Everett AW, Sparrow MP, and Taylor RR. 1979. Early changes in myocardial protein synthesis in vivo in response to right ventricular pressure overload in the dog. J. Molecular and cellular cardiology. 11:1253-1263

[5] Haschemeyer AEV, Persell R and Smith AK. 1979. Effect of temperature on protein synthesis in fish of the galapagos and Perlas islands. Comp Biochem. Physiol 64B:91-95

[6] Lindsay DB, Dauncey MJ, barker PJ, and Ingram DL. 1988. Protein synthesis and degradation after acclimation to different environmental temperatures and energy intakes. J. therm. Biol. 13:79-83

[7] Arends J and Bier DM. 1991. Labelled amino acid infusion studies of in vivo protein synthesis with stable isotope traces and gas chromatography-mass spectrometry. Analytica Chimica Acta 247:255263

[8] Walrand S, Guillet C, Gachon P, Giraudet C, Rousset P, Vasson MP, and Boirie Y. 2005. Insulin regulates protein synthesis rate in leukocytes from young and elderly healthy humans. Clinical Nutrition 24: $1089-1098$

[9] Harber MP, Dickinson JM, Crane JD, Trappe SW, and Trappe TA. 2011. Influence of tracer selection on protein synthesis rates at rest and postexercise in multiple human muscles. Metabolism Clinical and Experimental. 60:689-697

[10] Jonker R, Deutz NEP, Erbland ML, Anderson PJ, and Engelen MPKJ. 2014. Hydrolyzed casein and whey protein meals comparably stimulate net whole-body protein synthesis in COPD patients with nutritional depletion without an additional effect of leucine co-ingestion. Clinical Nutrition 33: 211-220 
[11] Jourdan M, Nair KS, Carter RE, Schimke J, Ford GC, Marc J, Aussel C, and Cynober L. 2014. Citrulline stimulates muscle protein synthesis in the post-absorptive state in healthy people fed a low-protein-diet--- A pilot study. $\quad$ Clinical Nutrition. http://dx.doi.org/10.1016/j.clnu.2014.04.019

[12] Pocrnjic Z, Mtthews RW, rappaport S, Haschemeyer AEV. 1983 Quantitative protein synthetic rates in various tissues of a temperate fish in vivo by the method of phenylalanine swamping. Comp. Biochem. Physiol. 74B:735-738

[13] Mays PK, McAnulty R and Laurent GJ. 1991. Age-related changes in rates of protein synthesis and degradation in rats tissues

[14] Emery PW and Ghusain-Choueiri A. 1995. The local and systemic effect of minor injury on muscle protein synthesis in the rat. Int. J. Biochem. Cell Biol. 27:815-820

[15] Egerland A, Reynier JP, Believre O, Dicostanzo J, Obled C and Arnal M. 1996. Protein synthesis measurement in cancer patient with ${ }^{13} \mathrm{C}$ valine. Clin. Chimica Acta 252:51-60.

[16] Masanes R, Fernandez-Lopez JA, Alemany M, Remesar X, and RafecasI. 1999. Effect of dietary protein content on tissue protein synthesis rates in zucker lean rats. Nutrition Research. 19:1017-1026

[17] Gasier HG, Previs SF, Pohlenz C, Fluckey JD, Gatlin DM, and Buentello JA. 2009. A novel approach for assessing protein synthesis in channel catfish, Ictalurus punctatus. Comp. Biochem. and Physiol. 154B: 235-238

[18] Chevalier L, Bos C, Gryson C, Luengo C, Walrand S, Tome D, Boirie Y, and Gaudichon C. 2009. High-protein diets differentially modulate protein content and protein synthesis in visceral and peripheral tissue in rats. Nutrition. 25:932-939

[19] Butteiger DN, Cope M, Liu P, Mukherjea R, Volpi E, Rasmussen BB, and Krul ES. 2013. A soy, whey, and caseinate blend extends postprandial skeletal muscle protein synthesis in rats. Clinical Nutrition. 32:585-591

[20] Garlick PJ and Cersosimo E. 1997. Techniques for assessing protein and glucose kinetics. Bailliere's clinical endocrinology and metabolism. 11: $629-644$

[21] U Ulyarti. 2014. Validasi metode flooding dose untuk mengukur laju sintesis protein pada sel Caco-2. Journal of the Indonesian Society of Integrated Chemistry 6(1).

[22] Tuvdendorj D, Chinkes DL, Bahadorani J, Zhang X-j, Sheffield-Moore M, Killewich LA, and Wolfe RR. 2014. Comparison of bolus injection and constant infusion methods for measuring muscle protein fractional synthesis rate in humans. Metabolism clinical and experimental. doi:10.1016/j.metabol.2014.09.009

[23] Coeffier, M Claeyssens S, Hecketsweiler B, Lavoinne A, Ducrotte P and Dechelotte P. 2003. Enteral glutamine stimulates protein synthesis and decreases ubiquitin mRNA level in human gut mucosa. AM J Physiol Gastrointest Liver Physiol 285:266-G273

[24] Jahoor F, Zhang X-j, Baba H, Sakurai Y and Wolfe RR. 1992. Comparison of constant infusion and flooding dose techniques to measure muscle protein synthesis rate in dogs. Am J. of Nutr 122:878887 